\title{
Hydraulic Model Investigation on Stepped Spillway's Plain and Slotted Roller Bucket
}

\author{
Alka Sunil Kote \\ Department of Civil Engineering, \\ Dr. D. Y. Patil Institute of Technology, \\ Pune, India \\ alkakote26@gmail.com
}

\author{
Prakash Baburao Nangare \\ Department of Civil Engineering, \\ Dr. D. Y. Patil Institute of Technology, \\ Pune, India \\ pbnangare@aissmscoe.com
}

\begin{abstract}
In ogee spillway, the released flood water from crest to toe possesses a high amount of kinetic energy causing scour and erosion on the spillway structure. The dam projects normally have a stilling basin as an energy dissipater which has specific energy dissipation limitations. The stepped spillway is a better option to minimize kinetic energy along the chute and safely discharge water in the river domain. The Khadakwasla dam is situated in Pune, Maharashtra (India), and has scouring and erosion issues on the chute of ogee spillway and on the stilling basin. The present study develops a physical hydraulic model for the dam spillway with steps, plain and slotted roller bucket as per IS Code 6934 (1998) and IS Code 7365 (2010). Experiments were performed at heads of $4 \mathrm{~m}$ (low head) and $6 \mathrm{~m}$ (high head) on the developed physical models, namely on the plain and slotted roller bucket model for the ogee spillway and the plain and slotted roller bucket model for the stepped spillway. It was found that the plain roller bucket of ogee spillway dissipates $81.26 \%$ of energy at the low head, whereas the stepped spillway with slotted roller bucket dissipates the $83.86 \%$ of the energy at the high head.
\end{abstract}

Keywords-stepped spillway; slotted roller bucket; physical hydraulic model; en ergy dissipation

\section{INTRODUCTION}

The toe portion of an ogee spillway plays an important role in dissipating specific energy and discharging floodwater safely on the downstream side. The released water acquires high kinetic energy at the toe of the spillway causing scouring and erosion of the channel bed. Stepped spillway is a better option to minimize the intensity of kinetic energy on its chute profile [1]. It discharges flood water safely and achieves significant energy dissipation along the chute due to the roughness of the steps. It thus reduces the length of the stilling basin. Many researchers performed experiments on stepped spillways and observed that energy loss mainly depends on the nondimensional parameter of the ratio of critical depth to step height $\left(y_{c} / h \leq 0.8\right)$ [2-6]. Energy dissipation is effective when the actual head is less than 1.4 times the design head [7, 8]. Stilling basin is generally preferred for guiding flow safely from the spillway to downstream river for energy dissipation [9]. The selection of stilling basin occurs on the basis of Froude number and the hydraulic jump characteristics. However, it requires a longer span to stabilize the flow in the downstream channel [10]. If the tail water is sufficient in the stilling basin for the development of the hydraulic jump, the roller bucket is the suitable option for energy dissipation $[11,12]$. The provision of roller bucket minimizes the length of stilling basin, scouring and erosion on a downstream bed of a river [13]. In Khadakwasla dam spillway located in Pune, India there are issues in stilling basin and on ogee spillway chute due to improper energy dissipation. Plain and slotted roller bucket is a good option to overcome the scouring and erosion issues of the dam spillway [14]. The present study focuses on a hydraulic model investigation regarding the Khadakwasla dam with plain roller bucket, slotted roller bucket and modifications on stilling basin for ogee profile stepped spillway.

\section{MATERIALS AND METHODS}

In this study, a new methodology is proposed to minimize the issues of scouring and erosion by improving the performance of energy dissipation and minimizing the length of stilling basin. Khadakawasla dam is located on the Mutha river basin with a cultivable area of $677.43 \mathrm{~km}^{2}$ and annual irrigation capacity of $621.46 \mathrm{~km}^{2}$ in Pune district. It supplies Pune city with $280.3 \mathrm{Mm}^{3}$ of water. The ogee spillway has a design discharge of $2700 \mathrm{~m}^{3} / \mathrm{s}$, crest height of $23.75 \mathrm{~m}$, design head of $4.29 \mathrm{~m}$ and 14 spans of $10 \mathrm{~m}$ width.

\section{A. Design of an Ogee Spillway}

A physical hydraulic model was developed on the existing tilting hydraulic flume in the FM laboratory and designed with a model scale ratio of 1:33 [15]. The model investigation is done as per hydraulic similarities. Froude's model law and the model dimensions are shown in Table I.

\section{B. Design of Stepped Spillway}

The stepped spillway model is designed for a single span of $10 \mathrm{~m}$ width with a scale of $1: 33$. The design is based on the Froude's model law as in [15]. The assumed hydraulic conditions are: i) The actual head should be less than 1.4 times the design head $[7,8]$, ii) tailwater depth is maintained in proportion with the sequent depth and the Froude number is more than $4.5[11,12]$. The condition for effective energy dissipation is: If $y_{c} / h=2.5$, the profile surface is effective for energy dissipation, for $2.5<y_{c} / h<6$, the effect is still appreciable and for $y_{c} / h>6$, the energy dissipation starts reducing [16]. In the proposed ogee stepped spillway model (on prototype) the following parameters are estimated: $y_{c}=3.35 \mathrm{~m}, h=1.33 \mathrm{~m}$, 
$y_{c} / h=2.51$. This satisfies the appropriate condition for effective energy dissipation. The effectiveness of stepped spillway is maximized for actual head lower than the design head [17]. Also, more steps on the spillway chute mean better energy dissipation and decrease of the hydraulic jump length. The heights of step are decided on the basis of dam height $\left(\mathrm{H}_{\mathrm{dam}}\right)$ [18]: $h_{\text {large }}=\frac{1}{20} H_{\text {dam }}, h_{\text {small }}=\frac{1}{40} H_{\text {dam }}$. Large steps are proposed in the design of stepped spillway with step height $h=40 \mathrm{~mm}$, tread $l=33 \mathrm{~mm}$, step angle $=50^{\circ}$ and number of steps $=12$.

TABLE I. HYDRAULIC MODEL FOR OGEE SPILLWAY DIMENSIONS

\begin{tabular}{|c|c|c|c|}
\hline Hydraulic dimensions & Prototype & Model (scale 1:33) & Unit \\
\hline Span width & 10 & 0.30 & $\mathrm{~m}$ \\
\hline Spillway height & 23.75 & 0.76 & $\mathrm{~m}$ \\
\hline Spillway length & 15.73 & 0.47 & $\mathrm{~m}$ \\
\hline Downstream slope & $0.75: 1$ & $0.75: 1$ & - \\
\hline Design discharge & 2700 & 0.41 & $\mathrm{~m}^{3} / \mathrm{s}$ \\
\hline Velocity & 0.59 & 0.10 & $\mathrm{~m} / \mathrm{s}$ \\
\hline Design head & 4.29 & 0.13 & $\mathrm{~m}$ \\
\hline
\end{tabular}

\section{Design of Roller Buckets}

Roller bucket is a relatively short structure compared to the hydraulic jump type of stilling basin used for energy dissipation. It requires tail water depth in the range of 1.1 to 1.4 times the sequent depth and Froude number greater than 4.5 [11]. Two types of roller buckets, namely plain and slotted roller bucket were considered. The roller bucket model is designed after the design of the Grand Coulee and Angostura dam type bucket (USA). The hydraulic parameters of roller buckets are designed as per [20] and displayed in Table II.

TABLE II. ROLLER BUCKETS AND STILLING BASIN DIMENSIONS

\begin{tabular}{|c|c|c|c|}
\hline $\begin{array}{c}\text { Energy } \\
\text { dissipater type }\end{array}$ & Hydraulic parameters & Prototype (m) & Model (mm) \\
\hline $\begin{array}{c}\text { Plain roller } \\
\text { bucket }\end{array}$ & Radius & 5.93 & 180 \\
\hline \multirow{4}{*}{$\begin{array}{c}\text { Slotted roller } \\
\text { bucket }\end{array}$} & Width & 0.3 & 9 \\
\cline { 2 - 4 } & Spacing & 0.3 & 9 \\
\cline { 2 - 4 } & Bottom width & 0.74 & 22 \\
\cline { 2 - 4 } & Top width & 0.30 & 9 \\
\hline \multirow{3}{*}{ Stilling Basin } & Height of lip from & 2.96 & 88 \\
\cline { 2 - 4 } & Buckession & 11.00 & 330 \\
\cline { 2 - 4 } & Sloping apron length & 18.67 & 560 \\
\hline
\end{tabular}

\section{Modifications in the Stilling Basin}

The performances of plain and slotted roller bucket were found satisfactory for discharge intensity less than $50 \mathrm{~m}^{3} / \mathrm{s} / \mathrm{m}$ [13]. Before modification of the stilling basin there is a need to locate the hydraulic jump for the developed models to fix its length. Hence, the stilling basin is modified with $\mathrm{V}$ notch and end sills (Figure 1). A stilling basin depression bucket and an end sill (sloping apron) were provided for flow control using a movable V-notch [20]. The modifications suggested in the stilling basin are: i) provision of a depression bucket to dissipate the hydraulic jump, ii) provision of sloping apron of $3 \mathrm{H}$ : $1 \mathrm{~V}$ slope, and iii) provision of a movable V-notch on the end sill.

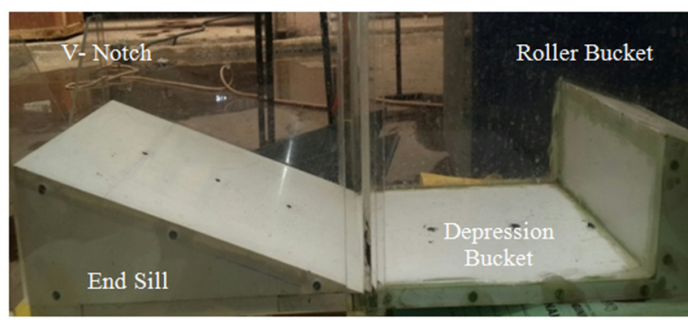

Fig. 1. Modified stilling basin with depression bucket

\section{E. Experimental Set Up}

The hydraulic model of the ogee profile stepped spillway was developed with a foam sheet, an acrylic sheet of $6 \mathrm{~mm}$ thickness and polyvinyl chloride sheet. The acrylic sheet was raised on both sides of the spillway chute by $300 \mathrm{~mm}$ for diverting floodwater towards the downstream side. Twenty piezometers were installed along the spillway chute to measure the static head using a multitube manometer. The piezometer taps with brass holes of $6 \mathrm{~mm}$ diameter were set at $45 \mathrm{~mm}$ intervals. The invert level of the roller bucket was kept above the river bed level in order to prevent the entry of silt-laden water. The developed set-up of the ogee stepped spillway model was attached to the tilting hydraulic flume of $6 \mathrm{~m}$ length, $300 \mathrm{~mm}$ width and $300 \mathrm{~mm}$ depth. The experiments were performed on ogee and stepped spillway hydraulic models with plain and slotted roller buckets as shown in Figure 2, with: i) plain roller bucket (OPRB model), ii) ogee slotted roller bucket (OSRB model), iii) stepped plain roller bucket (SPRB model), and iv) stepped slotted roller bucket (SSRB model). The laboratory experiments were conducted on a tilting hydraulic flume for $4 \mathrm{~m}$ and $6 \mathrm{~m}$ head. The experiments were performed at discharge of $0.0053 \mathrm{~m}^{3} / \mathrm{s}$ at low head $(4 \mathrm{~m})$ and $0.00649 \mathrm{~m}^{3} / \mathrm{s}$, at high head $(6 \mathrm{~m})$. Continuous flow of $0.0053 \mathrm{~m}^{3} / \mathrm{s}$ and $0.00649 \mathrm{~m}^{3} / \mathrm{s}$ was maintained in the flume which was kept horizontal. The water was pumped by a $3 \mathrm{Hp}$ motor and the total head on a model was measured by a pressure gauge attached at the inlet of the flume. In this model, provision was made to replace the plain roller bucket, slotted roller bucket, and steps. Performance with respect to specific energy and energy dissipation of all models was checked for varying heads and flume discharges. The experimental results of all models were compared with the hydraulic parameters for low and high water head.

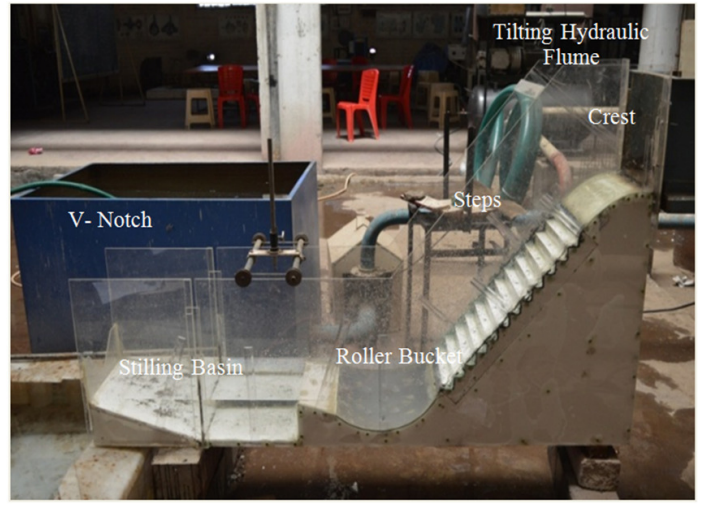

Fig. 2. Hydraulic model of the ogee rofile stepped spillway 


\section{RESULTS AND DISCUSSION}

The performance of OPRB, OSRB, SPRB and SSRB models was evaluated for $4 \mathrm{~m}$ and $6 \mathrm{~m}$ head by comparing the specific energy and energy dissipation along the chute surface. The hydraulic jump was observed for plain and slotted roller bucket at $4 \mathrm{~m}$ and $6 \mathrm{~m}$ head as shown in Figure 3.
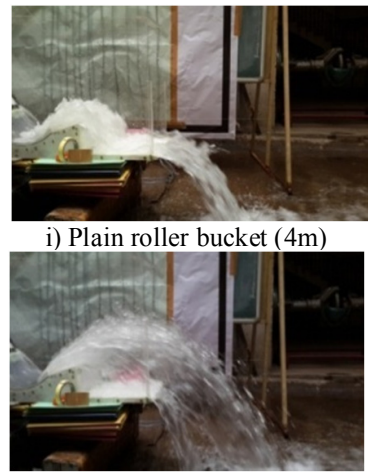

iii) Slotted roller bucket $(4 \mathrm{~m})$

Fig. 3. Hydraulic jump on roller buckets without stilling basin

\section{A. Hydraulic Jump Location on the Hydraulic Model}

The hydraulic jump is located on a model with a combination of roller bucket and steps for ogee profile stepped spillway (Table III). Figure 3 shows that the hydraulic jump is swept out from the hydraulic structure and falls on the stilling basin at a longer distance. According to the location of the hydraulic jump, the further part of the stilling basin type II is modified as shown in Figure 1. The performance of all models was evaluated for $4 \mathrm{~m}$ and $6 \mathrm{~m}$ head. The results regarding specific energy and energy dissipation are compared below.

TABLE III. HYDRAULIC JUMP LOCATIONS

\begin{tabular}{|c|c|c|c|}
\hline \multirow{2}{*}{ Head (m) } & \multirow{2}{*}{ Description } & \multicolumn{2}{|c|}{ Location of Hydraulic Jump } \\
\cline { 3 - 4 } & & Model (m) & Prototype (m) \\
\hline $\mathbf{6}$ & Plain roller bucket & 0.83 & 27.66 \\
\hline $\mathbf{6}$ & Slotted roller bucket & 0.85 & 28.33 \\
\hline $\mathbf{5}$ & Plain roller bucket & 0.80 & 26.66 \\
\hline $\mathbf{5}$ & Slotted roller bucket & 0.83 & 27.66 \\
\hline
\end{tabular}

\section{1) Specific Energy for Ogee and Stepped Spillway Models at Low Head (4m)}

The specific energy possesses by ogee and stepped spillway models along the chute of ogee profile are shown in Figure 4. In the ogee spillway model, it is seen that $82 \%$ of the specific energy is reduced by the OPRB model and $78 \%$ of the specific energy is reduced by the OSRB model due to the steps along the chute. In stepped spillway model, $58 \%$ of the specific energy is reduced in both SPRB and SSRB models. This shows that maximum reduction in specific energy is observed in ogee spillway models. This reduction in specific energy is observed in both models due to the formation of rollers and the separation of boundary layers below the toe end. In stepped spillway, it is observed due to the roughness of steps. Therefore, it is found that SPRB and SSRB model reduce the maximum specific energy at the toe end of the spillway at the low head of $4 \mathrm{~m}$.

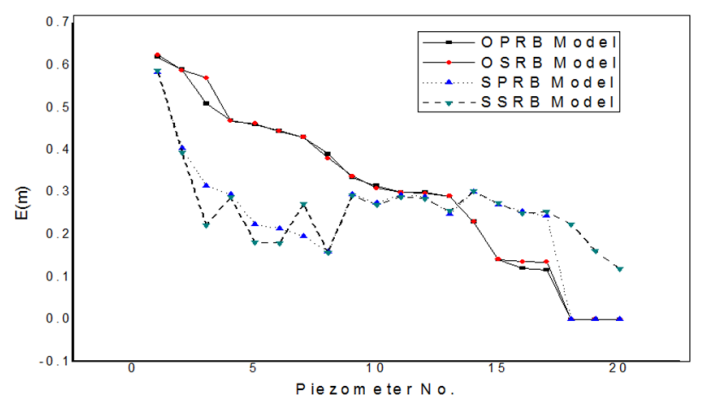

Fig. 4. Specific energy for ogee and stepped spillway model at low head

2) Specific Energy for Ogee and Stepped Spillway Models at High Head (6m)

For high head, it is observed that $79 \%$ of the specific energy is reduced in the OPRB model and $82 \%$ in the OSRB model. In stepped spillway, the reduction of the specific energy is $79 \%$ for the SPRB model and $57 \%$ for the SSRB model. The maximum reduction in specific energy is observed in OPRB, OSRB and SPRB models. This shows that slotted roller bucket of stepped spillway (SSRB) consistently reduces the kinetic energy from crest to toe end on the spillway chute surface. Thus, this model is more suitable for energy dissipation. It creates larger turbulence effect on steps and hydraulic jump falls on each step, which helps reduce the intensity of kinetic energy for the high head of $6 \mathrm{~m}$.

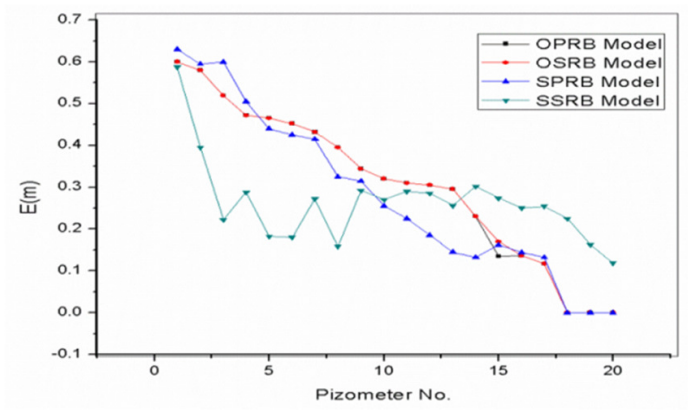

Fig. 5. Specific energy graphical representation for $6 \mathrm{~m}$ head

\section{3) Energy Dissipation for Ogee and Stepped Spillway Models at Low Head}

All model performances were tested for energy dissipation. It was observed that in stepped spillway, SPRB and SSRB models dissipate energy consistently along the spillway chute for low head. The energy dissipation is increased consistently with the SPRB model due to the combination of steps and roller bucket. Slotted roller bucket of stepped spillway is achieving energy dissipation consistently on its chute due to the turbulence effect and air entrainment occurring on each step. Regarding the ogee spillway models, the OPRB model dissipated $81.26 \%$ of the specific energy up to the spillway toe end for the $4 \mathrm{~m}$ head but it needs sufficient tail water in stilling basin for stabilizing the hydraulic jump. This shows that plain roller bucket of ogee spillway is a suitable dissipater for energy dissipation at the low head of $4 \mathrm{~m}$. 


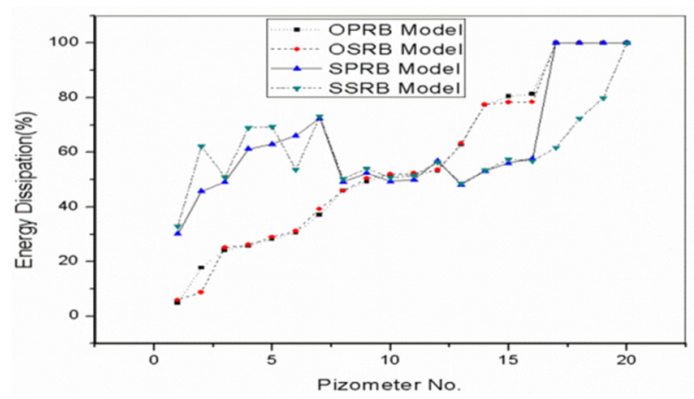

Fig. 6. Energy dissipation for ogee and stepped spillway at low head

\section{4) Energy Dissipation for Ogee and Stepped Spillway Models at High Head}

The specific energy dissipation for ogee and stepped spillway models at a high head $(6 \mathrm{~m})$ is shown in Figure 7. Considering stepped spillway models, it is observed that the SSRB model dissipates energy consistently on its chute surface because of the development of hydraulic jump on each step and its swept on the next step. The enhancement of energy dissipation is observed consistently up to the toe end on the model and observed due to the combination of steps and roller bucket. The energy dissipation by the SSRB model ranges from $65 \%$ to $80 \%$ on the spillway profile for the high head. However, in ogee spillway, OPRB and OSRB models dissipate $80 \%$ of the energy in the stilling basin at the downstream channel. In comparison with the other models, it was found that the SSRB model of stepped spillway dissipates maximum energy of $83.36 \%$ at the $6 \mathrm{~m}$ head.

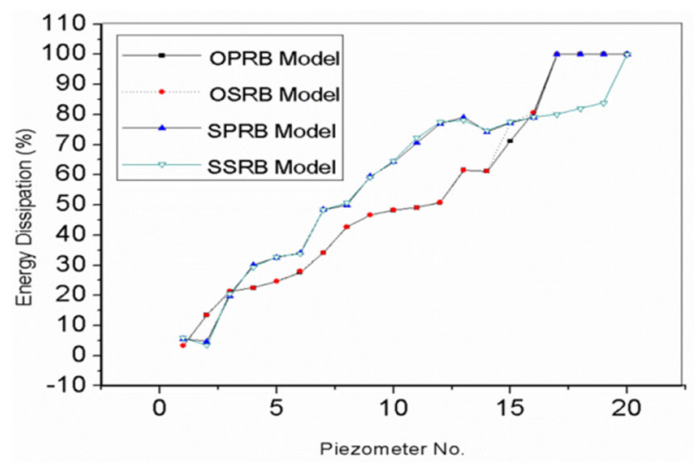

Fig. 7. Energy dissipation for ogee and stepped spillway at high head

\section{CONLCUSION}

Stepped spillway models are found to be highly effective for energy dissipation due to their combination of steps and roller buckets. It was also observed that the OPRB model of ogee spillway dissipated $80 \%$ of specific energy for the low head of $4 \mathrm{~m}$ but needed a longer span of stilling basin. Slotted roller bucket model (SSRB) of stepped spillway dissipated $83.86 \%$ of specific energy at the high head of $6 \mathrm{~m}$. In comparison with the other models, it was seen that the stepped spillway with slotted roller bucket dissipated maximum specific energy for a discharge of $0.00649 \mathrm{~m}^{3} / \mathrm{s}$ at $6 \mathrm{~m}$. Thus the slotted roller bucket (SSRB) of the stepped spillway model was found to be a suitable model to minimize scouring and erosion problems on the Khadakwasla dam spillway.

\section{ACKNOWLEDGEMENT}

The experiments were performed in the Fluid Mechanics Laboratory at All India Shri Shivaji Memorial Society College of Engineering, Pune.

\section{REFERENCES}

[1] M. Ashiq, A. Sattar, "Optimization of Energy Dissipation Works for Nai Gaj Dam Project", World Environmental and Water Resource Congress, Rhode Island, USA, May 16-20, 2010

[2] M. R. Chamani, N. Rajaratnam, "Characteristics of skimming flow over stepped spillways", Journal of Hydraulic Engineering, Vol. 125, No. 4, pp. 361-368, 1999

[3] G. C. Christodoulou, "Energy dissipation on stepped spillway", Journal of Hydraulic Engineering, Vol. 119, No. 5, pp. 644-649, 1993

[4] H. Chanson, "Comparison of energy dissipation nappe and skimming flow regime on stepped chutes", Journal of Hydraulic Research, Vol. 32, No. 2, pp. 213-218, 1994

[5] G. Degoutte, "Skimming flow in stepped spillway, discussion", Journal of Hydraulic Engineering-ASCE, Vol. 118, No. 1, pp. 111-113, 1992

[6] N. Rajaratnam, K. Subramanya, "Profile of the hydraulic jump", Journal of Hydraulic Division, Vol. 94, No. 3, pp. 663-674, 1998

[7] J. G. Chatila, B. R. Jurdi, "Stepped spillway as an energy dissipator", Canadian Water Resource Journal, Vol. 29, No. 3, pp. 147-158, 2004

[8] R. M. Sorensen, "Stepped spillway hydraulic model investigation", Journal of Hydraulic Engineering, Vol. 111, No. 12, pp. 1461-1472, 1985

[9] A. Liaghat, A. Adib, H. R. Gafouri, "Evaluating the effects of dam construction on the morphological changes of downstream meandering rivers (Case study: Karkheh River)", Engineering, Technology \& Applied Science Research,Vol. 7, No. 2, pp. 1515-1522, 2017

[10] Y. K. Tung, L. W. Mays, "Optimum design of stilling basins for overflow spillway”, Journal of the Hydraulic Division, Vol. 108, No. 10, pp. 1163-1178, 1982

[11] R. M. Khatsuria, Hydraulics of Spillways and Energy Dissipators, CRC Press, 2004

[12] S. K. Mazumder, P. L. Patel, "Model Study of a Ski-Jump Type Energy Dissipator", National Conference on Hydraulics and Water ResourcesHYDRO 2001, pp. 425-432, 2001

[13] V. V. Bhosekar, M. R. Bhajantri, B. S. Sunderlal, S. Patnaik, "Limitations of spillway roller bucket", Water and Energy International, Vol. 69, No. 7, pp. 47-54, 2012

[14] P. B. Nangare, A. S. Kote, "Experimental investigation of an ogee stepped spillway with plain and slotted roller bucket for energy dissipation", International Journal of Civil Engineering and Technology, Vol. 8, No. 8, pp. 1549-1555, 2017

[15] Bureau of Indian Standards, IS 6934 (1998): Hydraulic Design of High Ogee Overflow Spillways-Recommendations, Bureau of Indian Standards, 1998

[16] C. Chafi, A. Hazzab, A. Seddini, "Study of flow and energy dissipation in stepped spillway", Jordan Journal of Civil Engineering, Vol. 4, No. 1, pp. 1-11, 2010

[17] L. Peyras, P. Royet, G. Degoutte, "Flow and energy dissipation over stepped gabion weirs", Journal of Hydraulic Engineering, Vol. 118, No. 5, pp. 707-717, 1992

[18] A. H. K. Al-Shukur, S. K. H. Aal-Khalaf, I. M. A. Al-Sharifi, "Study of optimum safe hydraulic design of stepped spillway by physical models", International Journal of Scientific and Engineering Research, Vol. 5, No. 1, pp. 1356-1365, 2014

[19] Bureau of Indian Standards, IS 7365 (2010): Criteria for Hydraulic Design of Bucket Type Energy Dissipators, Bureau of Indian Standards, 2010

[20] W. H. Hager, L. Damei, "Sill-controlled energy dissipator", Journal of Hydraulic Research, Vol. 30, No. 2, pp. 165-181, 1992 